\title{
PSYCHE
}

Vou. 55 DECEMBER, 1948 No. 4

CHRYSOPID A (NOTHOCHRYSID A) COLLECTED IN MEXICO BY DR. A. DAMPF (NEUROPTERA) ${ }^{1}$

\author{
By Nathan Banks \\ Holliston, Massachusetts
}

Early in 1947 Dr. Dampf sent me a large number of Chrysopidæ, and later a smaller lot. Much of the material was collected in the 1920's, and almost all before 1938 ; so much of it had been in papers for many years it was fragile. Nearly a thousand specimens of Chrysopiella sabulosa were taken in the northern parts of Mexico; it occurs in the dry parts of Colorado, New Mexico and Texas. About half of the rest was taken in or near Mexico City or at least in the Federal District. Of the others the most interesting were specimens from the States of Guerrero and Chiapas; many I had not seen. Dr. Dampf intended to send a third lot, and to collect in the summer of 1947, but sickness, and his unfortunate death induce me to publish on what I have now. As in other cases, I have been greatly helped by the notes prepared by Prof. R. C. Smith on the types of Navas that he examined in his sojourn in Europe.

\section{Genus Chrysopa}

Synopsis of species in collection

1-Antennæ beyond second joint black (or very dark) for some distance, often paler before tip ................... 2 Antennæ not darkened beyond the second joint ...... 7

2-Black or reddish stripe or spot on cheeks; palpi pale

Cheeks pale, unmarked 3

3-Gradates bordered with brown, inner series not much

1 Published with a grant from the Museum of Comparative Zoology. 
nearer to outer series than to radial sector; second joint of antenna dark; three forks beyond end of medius before the acute tip of fore-wing, small species gradata Navas Gradates not bordered, and inner series almost twice as near to outer as to radial sector; four or four and one half forks beyond end of medius before the tip of wing, moderately large lateralis Guerin

4-Pronotum with a red line or stripe each side (not marginal) broken at the groove into two stripes; on face a dark spot below the basal joint; costal area (fore-wing) broader than the radial; five forks before the acute tip; head very broad .....tortolana $\mathrm{n}$. sp. Pronotum with an unbroken red line each side at or near margin; no mark below basal joint, costal area not broader than radial area

5-Basal joint of antennæ without any spot or line; gradates parallel and inner much nearer to the outer row, wings slender, third cubital cell longer than second everes Bks. Basal joint with a dark line or a spot

6-Gradates divergent, inner row fully as near to radial sector as to outer row, not bordered, each gradate hardly its length from next; hairs on veins very short sarta Bks. Gradates parallel, inner row much nearer to outer than to radial sector; each gradate usually its length or more from next, small species............ berlandi Navas

7-No dark mark on cheek, nor a band or spots on face

A distinct reddish or darker mark on cheek, sometimes a band on face

8-Basal joint of antennæ without a mark or stripe; palpi lined with dark, last joint dark; no red on vertex castalia n. sp.

Basal joint of antennæ with a mark or stripe

9 -Basal joint with two dark stripes; one continued on vertex for a short distance; palpi pale, last joint partly dark arioles Bks. Basal joint with but one dark stripe or spot 10 
10-Almost all cross-veins and the gradates of fore wing very dark; from the third cubital cell but one vein to margin, but four or five inner gradates; two or three forks beyond medius tolteca Bks. Costals and some other cross-veins dark only in middle, from third cubital the usual two veins to margin, six or seven inner gradates, and four or four and one-half forks beyond end of medius before the acute tip; pronotum plainly broader behind than in front; palpi pale caligata Bks.

11-A distinct dark or reddish band (or two lunules) across the face just below the base of antennæ, often also a lower band

No band across face

12-Second joint of antenna black; vertex with two spots in front, sometimes also behind; pronotum unmarked; venation mostly green, costals often dark at ends; five or six forks beyond end of medius before tip or fore wing mexicana Bks. Second joint of antennæ not dark 13

13-Vertex without marks except a red line close to each eye; venation, including gradates, pale; face-marks are red; five forks beyond end of medius before wing-tip; inner gradates near the outer row.

acolhua n. sp.

Vertex with dark or reddish marks near middle; inner gradates about as near to radial sector as to outer row

14-Pronotum without lateral dark stripes; vertex with a red thrice-forked mark; cross-veins mostly brown, divisory cell not twice as long as broad at base; three and a half or four forks beyond end of medius trifurcata n. sp. Pronotum with a dark or black stripe each side; vertex with two parallel lines near middle, sometimes connected in front; lateral lobes of meso- and metanotum more or less rufous; anal veins black for some distance

15-Venation (including gradates) largely pale green; pronotal stripes broad, reach side margin. 
In fore wings many cross-veins (including gradates) black; pronotal stripes slender, not reaching to side margin tezcucana n. sp.

16-Pronotum with two red spots each side, separated by the groove, cheek with a red streak from lower inner edge of eye; basal antennal joint quite long; fore wings with the gradates and many cross-veins dark, inner gradates nearer to the radial sector, and more or less divergent from the outer row...bouvieri Navas Pronotum not so marked

17-Pronotum with two small dark spots in front part; basal antennal joint very short and much rounded on inner side; some red on vertex near antennal sockets; gradates and most other cross-veins dark; pronotum plainly broader behind than in front, reddish on anterior corners exotera (?) Navas Pronotum without two dark spots

18-Pronotum with a distinct red lateral stripe each side ; palpi partly dark ............................................................... 19

No red lateral stripe on pronotum ………..................... 20

19-Vertex with a transverse reddish area behind antennæ; each lateral reddish stripe fully its width from the side margin of pronotum; wings not especially slender quadornia n. sp. No reddish on vertex, reddish stripes on pronotum are on the side margin of pronotum; wings noticeably slender, second and third cubital cells more elongate than usual marginata (?) Navas

20 -Gradates in the front wing plainly dark ................ 21 Gradates in both wings wholly pale green; basal joints of antennæ rather widely separated

21-Pronotum broadly green on sides, also lateral lobes of meso- and metanotum; basal antennal joints well separated, short but not much swollen on inner side; cheeks broadly red, palpi partly black; many crossveins dark incisa n. sp. Pronotum not broadly green on sides; cheeks reddish; last joint of palpi black, gradates dark, most other cross-veins pale comanche var.? 22 - Cheeks with a black line or streak, often some red 
adjoining; palpi pale californica Coq. Cheeks reddish, usually rather broadly; last joint of palpi black comanche Bks.

Chrysopa nahoa sp. nov.

Figures 18, 21

Green ; face with two maroon bands; one from just below eyes and across clypeus, the other just below antennæ, this one has an extension from the middle between the antennæ to vertex where it divides and extends laterally as a narrow streak just above antennal sockets to the eyes; the median lobe of vertex has two short parallel red streaks, and there is also a slender red line close to each eye; palpi partly black; antennæ pale, the basal joint rather more red at tip. Pronotum pale in middle and each side with a broad maroon stripe; the meso- and metanotum are pale in middle and broadly pale reddish on the lateral lobes; the abdomen has a narrow maroon stripe on each side. The pronotum is almost as long as broad behind, and about one-third narrowed in front.

In the fore wing the subcosta is black to beyond the divisory cell, and many costals dark at one end; the first and second anal veins are also dark (maroon), and their branches are dark on base; elsewhere the venation (including gradates) is largely greenish; the costal area is not as broad as the radial area; the divisory cell ends beyond cross-vein, both sides convex; there are nine cubitals beyond end of divisory cell. In fore wing there are eight outer and seven inner gradates, in parallel rows, inner scarcely nearer to outer than to the radial sector, the first four of inner series disjoints the sectorals a little; in the hind wing there are seven gradates in each row, parallel, and the inner toward end nearer to radial sector than to outer row. The radial area is only a little broader than the costal area, the costals numerous, twenty-five before the stigma, beyond the last there are none in stigmal area, but six in the subcostal area. The cubital area is about two thirds of the marginal area. In hind wing the costal cells are much longer than high. The hairs on all veins are rather short. 
Length of fore-wing, $14 \mathrm{~mm}$., width $4.3 \mathrm{~mm}$.

One from La Venta, southwest of Mexico City, 2800 m. alt., forest, 22 May.

Type: M.C.Z. no. 27994.

Chrysopa mexicana Bks.

Figures 13, 17, 20, 37

The venation is largely green; there are twenty-four costals, dark at upper end; the fourth and fifth slightly sinuous; eight inner gradates, nine outer, parallel, inner much nearer to outer than to radial sector; costal area about as broad as radial, cubital area about two-thirds of marginal area ; in hind wing six inner and seven outer gradates, placed as in fore wing. In both wings several of the sectorals are bent by the inner gradates; in fore wing six forks beyond end of medius before the wingtip. Palpi lined and last joint almost wholly black; the hairs on veins are quite long and reach half way across the slender costal cells.

From Presa San José, San Luis Potosi, 23 November.

Chrysopa acolhua sp. nov.

Figure 5

Face with a reddish lunule under base of each antenna; a narrow, reddish band below from under each eye and across base of clypeus, latter with a reddish spot each side; palpi mostly pale, but marked with dark; antennæ pale, basal joint in front with an elongate reddish streak or triangle on the lower part; vertex with a red border each side close to eye, and a more narrow border to upper side of the antennal sockets, united to form an acute angle between antennæ. Pronotum much broader than long; each side is broadly reddish brown, leaving a much more narrow pale median area; thorax and abdomen without markings (but possibly with some when fresh).

Wings long and moderately slender, venation pale, stigma scarcely darkened; costal cells on basal half of wing not numerous, and few, if any, twice as high as long, 20 costals before stigma, last four very short; divis- 
ory cell ends a little beyond cross-vein, fully twice as long as broad, six cubitals beyond; in fore wing eight outer and five inner gradates, in hind wing seven outer and four inner, in both wings the inner row is much nearer to the outer than to the radial sector, at junctions the sectorals are slightly disjointed; costal area plainly not as broad as radial area ; cubital area as broad as marginal area except toward base of wing.

Fore wing length 13-15 mm., width $3.8-4.2 \mathrm{~mm}$.

Type, from Pungarabato, Guerrero, Mexico (Jose Paner), 22 August.

Type: M.C.Z. no. 27997.

This species in many ways agrees with the description of $C$. varicosa Navas, but Navas says the inner gradates are arcuate, and the Smith Notes, "bowed up'. Here the inner gradates parallel to the outer. Two specimens from El Mante, Tamaulipas have the venation almost the same, but the cubital area is not so broad in proportion to the marginal area; the wings more slender, fore-wing $14 \mathrm{~mm}$. long, width $4.6 \mathrm{~mm}$.; the two lunules under antennæ of the typical form here form a band, barely broken in middle; I presume they are a form of the same species.

\section{Chrysopa tezcucana sp. nov.}

Figures 7, 11, 28, 31

Pale greenish; face with a rather broad maroon band below bases of antennæ, a zigzag black stripe under each eye, between are two pairs of rounded dark areas; a narrow dark stripe between bases of antennæ which forks on the vertex, but the forks soon become parallel; on each side of the pronotum is a red stripe, well separated from the margin, this stripe extends back on the lateral lobes of meso- and metanotum. Wings with green venation, the bases of the first and second anal veins are black; the costals are black, twenty before the stigma, the cells higher than broad, the third or fourth costal is more or less sinuous; bases of radial sector and of discoidal cell black, most of the radial cross-veins black, 
except ends, the cubitals and gradates also black. Six cubitals beyond the divisory cell, latter about three times as long as broad; five or six gradates in each series, nearly parallel, and the inner nearer to radial sector than to the outer row; radial area much broader than costal; the cubital area about two-thirds of the marginal area. In hind wings five or six gradates in each row, about parallel, and inner nearer to radial sector than to the outer row; the inner row disjoints the sectorals in both front and hind wings; the costal cells much longer than high.

Length fore-wing $14.8 \mathrm{~mm}$., width $3.4 \mathrm{~mm}$.

Type from Lomas de Chapultepec, Mexico City, Mexico 8 August, also Cuernavaca, Mexico City, 26 April, the latter are a little smaller.

Type: M.C.Z. no. 27993.

\section{Chrysopa trifurcata sp. nov.}

Figures 1, 2, 32

Head pale, with pale red marks on face and vertex; face broad, a narrow band below antennæ, making two curves, a broad red spot below each eye; in middle a transverse mark rounded above and with two projections below, enclosing a median pale spot. On vertex a mark starting between the antennæ, giving off each side a streak to margin upper edge of antennal sockets, shortly behind the median streaks forks again, and each fork gives off a branch to the eye, the fork still curving outward and reaching the hind border, each end being fully twice as near to eyes as to each other.

The pronotum shows no definite markings, but the lateral lobes of mesonotum are partly suffused with reddish and some faint reddish in some of the grooves. Abdomen dark above (possibly reddish alive).

Wings with pale veins; in fore wings the gradates and many cross-veins pale brown, some almost margined. Costal area almost half as broad as radial area; 18 costals before stigma, none sinuous, cells about as long as high; divisory cell is very broad, not twice as long as broad, the oblique base occupies about three-fourth of 
the cross-vein. From the third cubital cell there is but one vein behind, but it forks, equally in both wings, only one branch behind from the fourth cell; six cubitals beyond end of divisory cell. In fore wings five gradates in each row and almost parallel, but both rows slope upward more than usual, the inner row much nearer to radial sector than to the outer row; the inner gradates strongly disjoint the sectorals; the median vein ends further out on margin than usual, the end being as far out as the end of the stigma.

In hind wing there are four gradates in each row, the inner row much nearer to radial sector than to outer row, and also strongly disjointing the sectorals, the costal cells are mostly twice as long as high.

Length of fore wing $12.5 \mathrm{~mm}$., width $4.1 \mathrm{~mm}$.

From Navojoa, Sonora, 24 March, 1927.

Type: M.C.Z. no. 27995.

The marks on vertex resemble those given by Navas for his Leucochrysa delicata; but trifurcata is not a Leucochrysa; the face has various red marks; Navas says head etc. "subtota fusca." moreover he figures the pronotum broader behind, in trifurcata the sides are parallel.

\section{Chrysopa bouvieri Navas}

Figures 16, 20

From Vergel, Chiapas 18, 30 May, 3 June; Finca Germania, Chiapas, Sierra Madre del Sur, 20 June; Coffee Plantation, Sierra Madre del Sur, Chiapas 11 May; Eșperanza Plantation, Sierra Madre del Sur, Chiapas, 5 March, all in forest.

The red of the anterior spots usually extends forward onto the vertex as a line near each eye. Costal area very broad near base, equal to the radial area; 19 to 22 costals, the third usually slightly sinuous; three to four inner gradates and about eight outer, the inner more or less divergent and generally nearer the radial sector, first of inner gradates bends the sectoral at juncture; divisory cell full twice as long as broad; cubital area 
hardly two-thirds of marginal area. I believe that yucatanensis and divergens are synonyms.

Chrysopa tortolana sp. nov.

Face pale, no cheek mark, but a dark spot below each basal joint close to the socket, some irregular dark spots on basal joint and four to six joints beyond black (except second joint), beyond this some joints dark on one side; palpi pale; vertex and basal joints above faintly pink.

Pronotum with a narrow red line on each side of front part, and a shorter red line on posterior part, much more than its width from lateral margin, rest of thorax very pale yellow. Venation green; gradates black, several of the longer radials dark near upper end, but not at end; some of the longer costals marked the same.

Basal joint of antennæ very short and small; pronotum a little broader than long in middle, sides nearly parallel. Wings rather broad; costal and medial areas both very broad at widest part, but the costal plainly the broader; eighteen costals, none sinuous; marginal area much broader than cubital, in fact almost twice as broad beyond the third cubital cell; third cubital cell as long as and broader than the second; divisory cell about twice as long as broad; six cubitals beyond; medius ends far before tip, full five forks before the tip.

In fore-wing six inner and seven outer gradates, each gradate well separated from next; rows not parallel, the inner as near radial sector or nearer toward end than to the outer row; in hind wing four inner, six outer gradates, inner nearer to radial sector for most of length; in hind wings all veins green.

Length of fore-wing $14 \mathrm{~mm}$., width $4 \mathrm{~mm}$.

One from Vergel, Chiapas, 4 June, at light.

Type: M.C.Z. no. 27998.

This species resembles $C h$. tetrasticta, but the antennæ are black for a short distance and partly black for a greater distance, also the black on face, and the crossveins not clouded separate it; the red marks on pronotum are more slender than in tetrasticta. 
Chrysopa arioles Bks.

Figures 6, 21

From Esmerelda, Chiapas, Sierra Madre del Sur; Vergel, Chiapas, 18 May; El Dorado, Sinaloa, 23 Jan. and Matemorelos, Nuevo Leon, 3 Jan.

The divisory cell is very slender; costals 16 to 18 , costal area hardly as broad as radial area, the third or fourth costal is plainly sinuous. There is no mark on the cheek, the antennal sockets are usually margined with red, the inner stripe on basal joint is continued back on the vertex.

Chrysopa caligata Bks.

From Vergel, Chiapas, 29 May, 17 May, 22 May, 1, 4 June; Esmerelda, Chiapas, Sierra Madre del Sur, 11 May.

The divisory cell is much like that of arioles, but often a little broader; about 18 to 20 costals, the third or fourth is sinuous; there is ordinarily no mark on cheek nor face, but one of the Vergel specimens has a black streak from eye toward mouth, ending in a slender point on clypeus; the basal joint of antennæ is wholly black (instead of the two black marks); in this specimen and several of the others the gradates are faintly bordered with brown; the marks on basal joint in these usually black, or almost so.

\section{Chrysopa tolteca Bks.}

Figure 27

From Centinella, Colima, 28 Jan., El Mante, Tamaulipas, 7 Aug., Villa Hermosa, Tabasco, 14 June, 13 Aug., Navojoa, Sonora, 24 March, Vergel, Chiapas, 12 May, Frontera, Tabasco, 7 June.

The costal area is not nearly as broad as radial area, 14 to 15 costals, the third or fourth often a little sinuous; practically all the cross-veins and the gradates of fore wing are black. In hind wing the gradates dark, most other veins pale; the costal cells fully twice as long as broad. In neither wing do the gradates bend the sec- 
torals; the third cubital cell has but one branch to the hind margin, the next cell has two. The numerous specimens I have seen have but one branch to the hind margin.

Chrysopa sarta Bks.

Figure 15

One from Vergel, Chiapas, 12 May, 1935.

It has but one marginal vein from the third cubital cell, and that from beyond the middle of cell. The costal area is not quite as broad as the radial area; about twenty costals, none plainly sinuous; all the costal cells before the middle of wing are higher than broad, some twice as high. The inner gradates start from near the penultimate cubital and plainly diverge from the outer row; beyond end of medius there are four marginal forks before the acute tip; the cubital area is fully two-thirds of the marginal area.

\section{Chrysopa berlandi Navas}

From Esmerelda, Sierra Madre del Sur, Chiapas, 11 May 1937, and several from Vergel, Chiapas, 22, 23, 29 May, 4 June.

There are about seventeen costals, the third or fourth a little sinuous; the costal area plainly less broad than the radial. The gradates in parallel rows, the third cubital cell much narrowed at base. The cubital area is but little more than half the marginal area; three forks beyond end of medius before acute tip.

Chrysopa gradata Navas

One from Vergel, Chiapas, 17 May, 1 June, at light. It is much like berlandi, but with a distinct black stripe on each cheek.

The second vein from the third cubital cell to margin is (or almost) interstitial with the end of the third cubital cell; just as it is in berlandi.

Chrysopa everes Bks.

One from Vergel, Chiapas, 28 May, at light.

The first and second joints of antennæ are wholly pale 
rufous, without marking. This has a very short face; seen from the side the part in front of eye is not quite as long as the eye. The wings are longer and more slender than in $C$. berlandi.

\section{Chrysopa lateralis Guerin}

Figure 22

One from Esperanza, Chiapas, 14 June, another from Vergel, Chiapas, 31 May.

Pronotum with a reddish stripe each side, a short distance from margin; costals (19) and gradates in fore wings all dark, other venation mostly pale greenish; three inner and seven outer gradates, parallel, and inner row much closer to outer than to radial sector, sectorals not bent by gradates; divisory cell fully three times as long as broad, both sides curved, ends beyond cross-vein; six cubitals beyond. Costal area not quite as broad as radial; no costal cells twice as high as broad; cubital area not quite so broad as marginal area. In hind wing venation pale, three inner and six outer gradates, parallel and inner near the outer.

Chrysopa incisa sp. nov.

Figure 8

Head, thorax, leg's, antennæ pale, under the eye there is an elongate, reddish stripe, without any inner reddish streaks, more like californica, but not black; palpi pale, darker at tip, lower end of head in two divergent points. Pronotum green, with a white stripe along the middle, and extending onto mesonotum; pronotum about as long as broad, sides nearly parallel, lateral lobes of meso- and metanotum green; abdomen of male with a pale median stripe above, with white hairs.

Wings with venation pale green, few darkened veins, and then at one end. Radial area hardly broader than costal area, 20 costals, third and fourth sinuous; second and third cubital cells about equal, divisory cell ends just before cross-vein, cell about two and one-half times as long as broad, six cubitals beyond; cubital area hardly 
two-thirds the width of marginal area. In fore wing six or seven outer gradates, and three of four inner ones, inner about one-half way between, the first inner bends the sectoral, others but little.

In hind wings five outer and four inner gradates, inner about one-half to radial sector; the costal cells very much longer than high.

Length of fore wing 11.5-13. mm., width 3.8-4. mm.

From Ciudad Juarez, Chihuahua, Mexico, 4 June 1927, and Hermosillo, Sonora, 23 March 1927.

Type: M.C.Z. no. 28000.

Chrysopa quadornia sp. nov.

Figures 23, 36

Thorax, legs, antennæ pale yellowish, head somewhat suffused with reddish, broadly red below eye, palpi almost wholly black, vertex with a transverse reddish area above antennæ, lower face at end only slightly emarginate. Pronotum with a reddish stripe on each side, not near margin, posterior portion with a transverse reddish streak.

Wings with pale green venation, some costals, radials, cubital cross-veins, and gradates darkened in middle or at one end, but none really black, the gradates darkest. Radial area a little broader than costal; radial sector not strongly curved, 20 costals, third and fourth plainly sinuous, cells rather high, but few twice as high as broad; divisory cell ends much before the cross-vein, about two and one-half times as long as broad, base full half of cross-vein; six cubitals beyond the divisory. Six or seven gradates in each row in fore wing, rows parallel, the inner row almost as near radial sector as to outer row, first of inner row plainly bends the sectoral; second cubital cell scarcely as long as third; cubital area about two-thirds of marginal area.

In hind wing four inner and six outer gradates, placed as in fore wing; a few costal cells about twice as long as broad, but mostly shorter.

Length of fore-wing $12.2 \mathrm{~mm}$., width $3.5 \mathrm{~mm}$.

One from Acapulco, Mexico, 19 Dec. 1924.

Type: M.C.Z. no. 28001. 
Chrysopa castalia sp. nov.

Figures 4, 30

Head, thorax, antennæ pale yellowish, no marks on head; the outer side of the last two joints of palpi is black; antennæ wholly pale, basal joint short, tapering above, third fully twice as long as broad; vertex not as broad proportionally to eyes as in californica or comanche. Pronotum narrowed in front, behind about as long as broad, the hind border strongly convex, an elevated transverse ridge in front of the groove.

The venation is mostly greenish; a couple of crossveins near base, the gradates in both wings are dark, also the last cubital cross-vein. There are 21 costals, the fourth, fifth, and sixth sinuous; the divisory cell is about two and one-half times as long as broad, both sides convex, and ends just beyond the cross-vein. Costal area not quite as broad as radial area, the first section of radial sector curved. Second cubital cell a little longer than third, six cubitals beyond the divisory cell; gradates parallel, five inner, seven or eight outer, inner a little nearer to outer than to radial sector, first inner plainly bends the sectoral, other much less; cubital area fully two-thirds of the marginal area, veins sparsely haired, but hairs fairly long.

In hind wings seven outer and five inner gradates, inner ones fully as near to radial sector as to outer.

Length of fore wing 14 . mm., width $4 . \mathrm{mm}$.

One from Santa Engracia, Tamaulipas, 3 Febr. 1936. Type: M.C.Z. no. 28002.

\section{Chrysopa exotera Navas}

Figures 10, 24

One specimen from Cuernavaca, Morelos, 20 Febr. 1933, seems to agree with the description; face marks much as in C. comanche, but practically all cross-veins black or dark. In this specimen the two submedian depressions on the front part of pronotum are almost black. 


\section{Chrysopa marginata Navas(?)}

Figure 19

Several specimens of this delicate form with the distinct red margins of pronotum; it has the cheek mark much as in comanche, but the wings are more slender.

Hacienda Nainari, Sonora, 10 August, in the desert; El Dorado, Sinaloa, 23 Jan.; Cuernavaca, Morelos, 2 March; and Ayotzinapa, Guerrero, 14 Jan. 1941. Navas gives a very brief description of marginata as a variety of $C$. externa; not enough for certainty.

\section{Chrysopa comanche var.}

About 6 specimens are like comanche, but the gradates distinctly dark. Hacienda Nainari, Sonora, 15 Aug. 1927, desert; Lomas de Chapultepec, 27 June, 1942, and four from Santa Engracia, Tamaulipas, 2, 3, 20, 25, February, 1936. Two other specimens from Santa Engracia, 3 February, 1936, have green gradates and appear typical comanche.

\section{Chrysopa comanche Bks.}

This is a very common species. San Jacinto, Mexico City, 3 Febr. 14 March, 2, 8, 24 May, 4, 7, 12, June, 23 July; Cuernavaca, 29 March, 7 April; Torreon, 6 July; Montemorelos, Nueva Leon, 3 June; Hacienda Buenavista, Coahuila, 10 June; Hacienda Fresno, near Torreon, 11 June; Hacienda Nainari, Sonora, 10, 15 Aug; La Barca, Jalisco, 20 May; Los Tablas, S. L. Potosi, 11 Oct., 23, 29 Nov.; St. Engracia, Tamaulipas, 3 Febr.; Jalapa, Vera Cruz, 20, 24 March; San Miguel Totolapan, Guerrero, 15 Aug.; Ayotzinapa, Guerrero, 14 Jan.; Acapulco, Guerrero, 19 Dec.; and Villago Arista near Arriaga, Chiapas, 24 May.

\section{Chrysopa californica Coq.}

Figures 3, 35

More common than $C$. comanche. San Jacinto, Mexico City, 2, 4, 8, 9, 24 May; 4, 7, 12, 20, 21, 22, June ; 23, 27 July; 11 Aug.; 18 Oct.; 16 Nov.; 14 March ; Torreon, Coa- 
huila, 19 June; Hacienda Santa Barbara, 16 July; Saltillo, Coahuila, 10 June; Santa Engracia, Tamaulipas, 3 June, 13 April; Granja Rodriguez, Nueva Leon, 6 June; Presa San José, S. L. Potosi, 23 Nov.; Hacienda Fresno, Torreon, Coahuila, 11 June; Hacienda Buenavista, Coahuila, 10 June; Navajoa, Sonora, 24 March; and Ciudad Juarez, Chihuahua, 4 July.

\section{Genus Chrysopiella}

Chrysopiella sabulosa Bks.

Figures 25, 26

The front of the basal joint of antennæ is usually wholly black, but sometimes with two parallel stripes, face with two submedian black dashes, stripe on cheek ending with a black dash, upward. About 15 to 22 costals, the third or fourth slightly sinuous; the radius extends far beyond end of subcosta so there are several (four or five) cross-veins from radius to margin; costal area not quite as broad as the radial area, radial sector for much of its length parallel to radius. The divisory cell is more than twice as long as broad, ends beyond the cross-vein, sometimes at end of second cubital cell; cubital area at widest not two-thirds of marginal area at widest part, both narrowed to tip; there are four or five outer gradates, rather widely separated; in hind wing five to six outer gradates; in fore wing the sectorals are curved, in hind wing several are sinuous.

One specimen has two inner gradates in fore wing, near the radial sector.

It is extremely common in northern parts of Mexico, and in desert regions in central and southern Mexico.

From Palomas, S. L. Potosi, 12 Oct.; Los Tablas, S. L. Potosi, 11 Oct.

Genus Eremochrysa

Eremochrysa punctinervis Mc Lach.

Saltillo, Coahuila, 10 June; Hermosillo, Sonora, 23 March; Lomas de Chapultepec, Mexico City, 23 Sept., 10 July, 6, 8 Aug.; Montemorelos, 3 June; Presa San 
José, San Luis Potosi, 23 July, 23 Nov.; Granja Rodriguez, Neuva Leon, 6 June; Hacienda Nainari, Sonora, 15 Aug.; Torreon, Coahuila, 6 June; Ciudad Juarez, Chihuahua, 14 July.

\section{Eremochrysa hageni Bks.}

From Bejuco, Guerrero, 3, 4 Sept.; Cuernavaca, 8 April.

\section{Genus Nodita}

The few species present in this collection can be sepa. rated by the following table.

1-Fully thirty costals before stigma; many costal cells more than three times as high as broad; about ten cubital cross-veins beyond the divisory cell; part of the radial sector dark; cubital area hardly one third the width of marginal alloneura Bks. Few, if any, more than twenty costal cross-veins ; few, if any, costal cells more than three times as high as broad; six to eight cross-veins beyond the divisory cell; cubital area nearly one-half or more of marginal area

2-A black spot on base of fore-wings

No such spot; but spots on side and ends of mesonotum

3-Costal area very broad near base, plainly a little broader than the radial area; inner gradate series starts at the penultimate cubital cross-vein sp. Costal area not as broad as radial area; inner gradate series starts much beyond the penultimate cubital cross-vein

4-Antennæ wholly pale punctata Bks. Antennæ from second segment out dark for ten or more joints maculata Navas

Nodita antennata Bks.

From Indian Village, Zoagochi, Sierra Juarez, Oaxaca, 24 June (Francisco Reyes coll.). 
Nodita maculata Nav.

From Vergel, Chiapas, 18 May; Villa Tabasco, 16 June.

Nodita punctata Bks.

From Yagalaxi, Sierra Juarez, Oaxaca, 29 Dec.; Vergel, Chiapas, 21, 26 May. Chrysopa salleana Nav., according to the Smith Notes, appears to be a synonym.

Nodita alloneura Bks.

From Esperanza, Chiapas, 30 May.

Genus Leucochrysa

Leucochrysa pretiosa Bks.

From Vergel, Chiapas, 19 May.

\section{Genus Meleoma}

Hagen (1861) described a Chrysopa innovata from Mexico. The type is in the Berlin Museum; I saw it in 1912, and noted it was a Meleoma, with a process between and below antennæ shorter than in our northern M. signoretti.

Banks (1899) described Meleoma mexicana from Mexico City, and later placed it (incorrectly) a synonym of innovata.

Navas (1914) described Chrysopa dolichartha from Guatemala; a female with extremely slender basal joint of antenna. The Smith notes say it is a Meleoma.

Navas (1928) described Meleoma titschacki from Costa Rica.

In the Dampf material are two species, both taken in Mexico City, two males and four females. The two males differ in the structure of head; one male and two females have a pair of short parallel red lines near the center of vertex. Navas says of titschacki that a "stria sanguinea longitudinali in vertice et occipite juxta oculos." The dolichartha has a much more elongate basal antennal joint than in any I have seen. So both of the Navas names do not apply to the Dampf material.

M. mexicana and the two species in the Dampf material 
are readily separated in the male by several characters. $M$. mexicana has two rather slender pointed horns from between the bases of the antennæ; the front of head (seen from side) is much sloping above; the others have the tip more vertical; in one (hageni) there are two small truncate, hairy plates between the antennæ, and the anterior lobe of head has a tuft of hair above; in the other (colhuaca) there is a small process, with a trilobed tip between the antennæ, and the basal antennal joint has a large lobe at inner base, bilobed above, and in the fore wing most of the radial cross-veins are swollen in the middle. The female of hageni has two short reddish stripes on the middle of vertex; I am not sure of the females of the two other species.

\section{Meleoma hageni sp. nov.}

Figures 12, 33

Pale greenish; face with a black streak from eye to mouth; last joint of palpi largely dark, lower side of basal joint of antenna reddish; the median lobe of vertex with two short parallel reddish stripes, not near the eyes; sides of pronotum slightly yellowish brown, a reddish brown mark on each side of anterior lobe of mesonotum. Wings with greenish venation, the gradates and costals of fore wings wholly black, sectorals, cubitals, and some other cross-veins dark at ends, branches from cubitus to hind margin remain green; in the hind wings the gradates and costals dark, most other venation pale.

Seen from the side the head of the male is short, the end blunt, on the part near to antennæ there is an erect median hairy process; the portion extending down from between the antennæ ends in two short, broad flat pieces, the outer corner of each projecting more than the rest. Each basal joint of antennæ is hollowed out in front, leaving a lobe at base and tip, this under surface is reddish; the median lobe of vertex is very broad.

Pronotum somewhat broader behind than in front, and in front a little broader than long.

The female has the same dark streak in cheeks, the palpi dark on outer side, the two short reddish lines on 
vertex (in some specimens faint or absent); antennæ pale, but in some with a faint reddish transverse mark on the front of basal antennal joint.

In the wings (both sexes) the divisory cell is about two and one-half times as long as broad, and ends beyond the cross-vein, the base occupies fully one-half of the cross-vein, seven cubitals beyond divisory cell, mostly oblique; gradates nine in each row, rows parallel in fore wing, in hind wing seven inner, eight outer row, in both wings the inner row is about as near to radial sector as to outer row; costal area not as broad as radial area, cubital area little more than one-half of marginal area, branches of cubitus sloping; about 25 or 26 costals, the fifth slightly sinuous.

Length of fore-wing + 17 . mm., width $6 . \mathrm{mm}$.

From Lomas de Chapultepec, Mexico City, 25 July, 4, 15, 22, 27, Aug., 22 Oct. The wings of the only male are crumpled, and probably about $14 \mathrm{~mm}$. long.

Type: M.C.Z. no. 27996.

Meleoma colhuaca sp. nov.

Figures 9, 14, 29, 34

Nale. Face, vertex, pronotum, greenish; thorax green on sides with a pale yellowish median stripe; vertex of head swollen, yellowish; abdomen dull green, venation also, many cross-veins at least partly black, tips of palpi black. Head similar to M. mexicana, the swollen front part with short erect hairs above; the antennæ very widely separated, the basal joint crowding the eye, near the inner base of each basal joint is a rounded lobe, the upper part plainly bilobed, between the two is a slender projection forward from the vertex downward, elongate, and faintly trilobed at tip. The basal joints are short, enlarged at tip, without elongate impression on lower inner side, but a slight impression on outer side where it rests against the eye. The vertex is swollen, roundedly triangular, the occiput is reddish. The pronotum is broadly dark green on each side, and pale yellowish in middle; the green (somewhat paler) extends over the lateral lobes of meso- and metanotum; the pronotum is 
much broader than long, the sides parallel, but close to head narrowed.

The wings are fairly long and slender; the gradates, costals, and some basal cross-veins black, many others dark at ends; the divisory cell ends at or near the end of the third cubital cell, it is about three times as long as broad, the base occupying one-half of base-vein; seven cubitals beyond end of divisory cell. About ten gradates in each series in the fore wing, sectorals scarcely bent by the gradates; in the hind wing nine inner and ten outer gradates; in both wings the rows are parallel and the inner row about as near radial sector as to the outer row.

The radial area is much broader than costal area; about thirty costals, the fifth sinuous; about fifteen radial cross-veins, in all, except the first two or three, the vein is swollen except at ends; likewise most of the sectorals are also swollen; the venation is densely haired, the hairs mostly fairly short, the costals however are not so thickly haired. The cubital area is about two-thirds of the marginal, both cubitals and marginals oblique; about twenty-eight costals, the fifth sinuous.

Length of fore wing $16 \mathrm{~mm}$., width $5.6 \mathrm{~mm}$.

One from Lomas de Chapultepec, Mexico City, 23 June. Type: M.C.Z. no. 27999.

\section{Explanation of Plate 18}

1. Chrysopa trifurcata, face.

2. Chrysopa trifurcata, vertex.

3. Chrysopa californica, basal antennal joint.

4. Chrysopa castalia, lower part of face.

5. Chrysopa acolhua, face.

6. Chrysopa arioles, vertex.

7. Chrysopa tezcucana, vertex, pronotum, mesonotum.

8. Chrysopa incisa, pronotum, left; lower part of face, right.

9. Meleoma colhuaca, basal antennal joints, and interantennal process.

10. Chrysopa exotera, pronotum.

11. Chrysopa tezcucana, face.

12. Meleoma hageni, side of head, and interantennal process.

13. Meleoma mexicana, side of head, and interantennal process.

14. Meleoma colhuaca, side of head. 


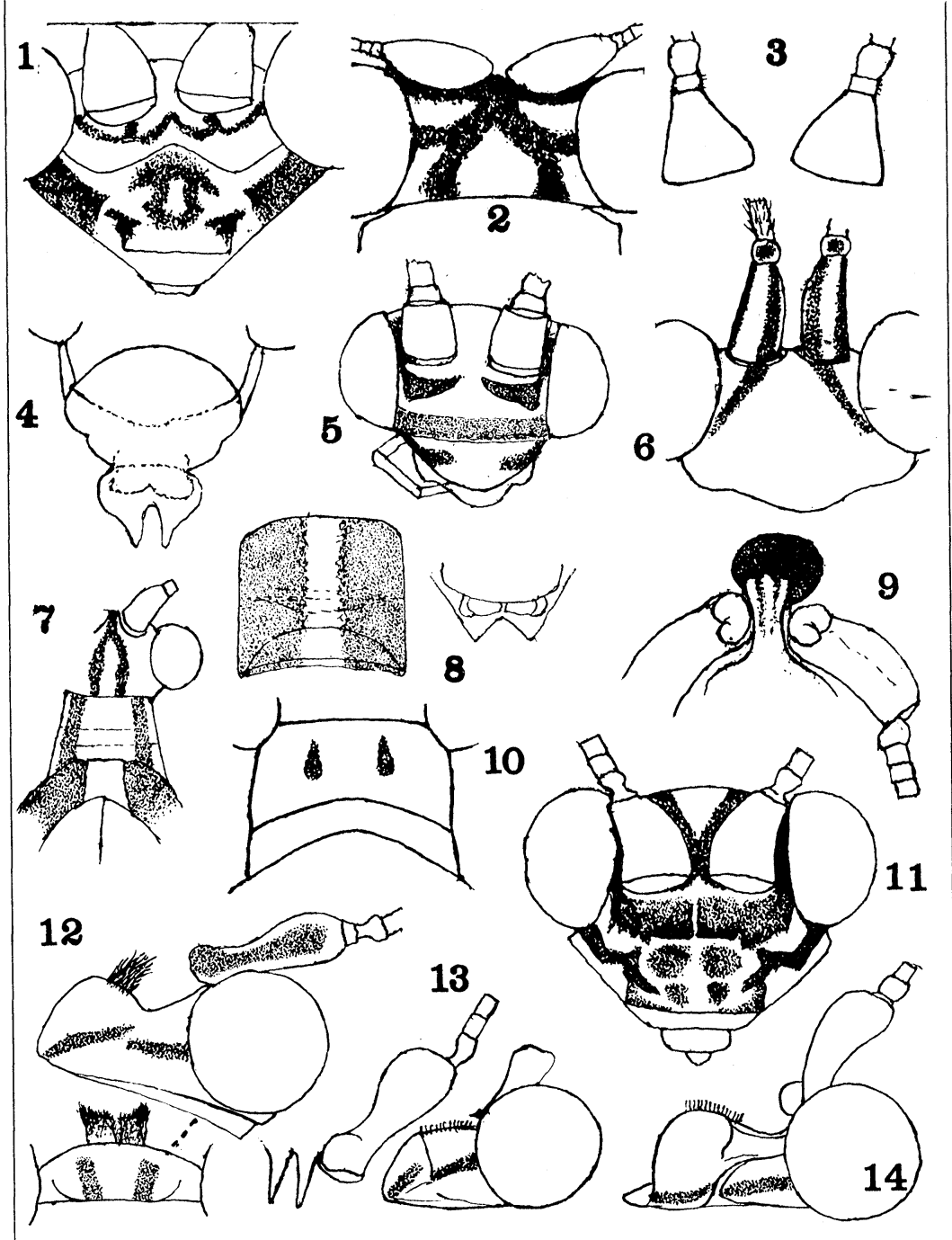

BANKS-CHRYSOPIDAE 
15. Chrysopa sarta, venation near divisory cell.

16. Chrysopa bouvieri, basal antennal joint.

17. Chrysopa mexicana, basal antennal joint.

18. Chrysopa nahoa, vertex and pronotum.

19. Chrysopa marginata, venation near divisory cell.

20. Costal area at stigma, above $C$. mexicana, below $C$. bouvieri.

21. Venation near divisory cell; above Chrysopa arioles, below C. nahoa.

22. Chrysopa lateralis, venation near divisory cell.

23. Chrysopa quadornia, pronotum.

24. Chrysopa exotera, basal antennal joint. 


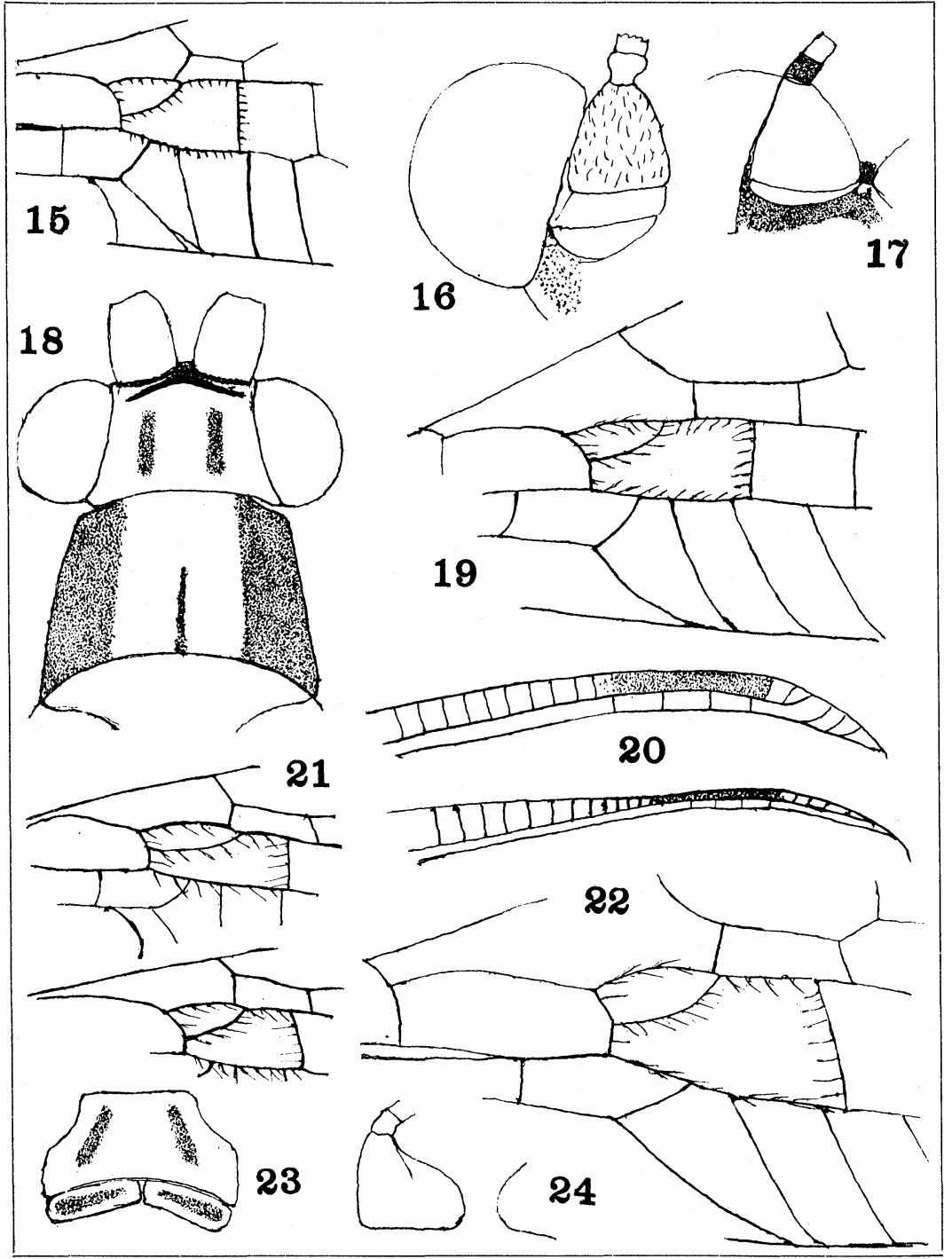

BANKS-CHRYSOPIDAE 
25. Chrysopiella sabulosa, venation near apex of fore wing.

26. Chrysopiella sabulosa, venation near divisory cell.

27. Chrysopa tolteca, venation near divisory cell.

28. Chrysopa tezcucana, basal antennal joint.

29. Meleoma colhuaca, swollen radial cross-veins.

30. Chrysopa castalia, basal antennal joints, and two beyond.

31. Chrysopa tezcucana, venation near divisory cell.

32. Chrysopa trifurcata, venation near divisory cell.

33. Meleoma hageni, venation near divisory cell.

34. Meleoma colhuaca, venation near divisory cell.

35. Chrysopa californica, anal area of fore wings.

36. Chrysopa quadornia, basal antennal joint.

37. Chrysopa mexicana, side of head. 


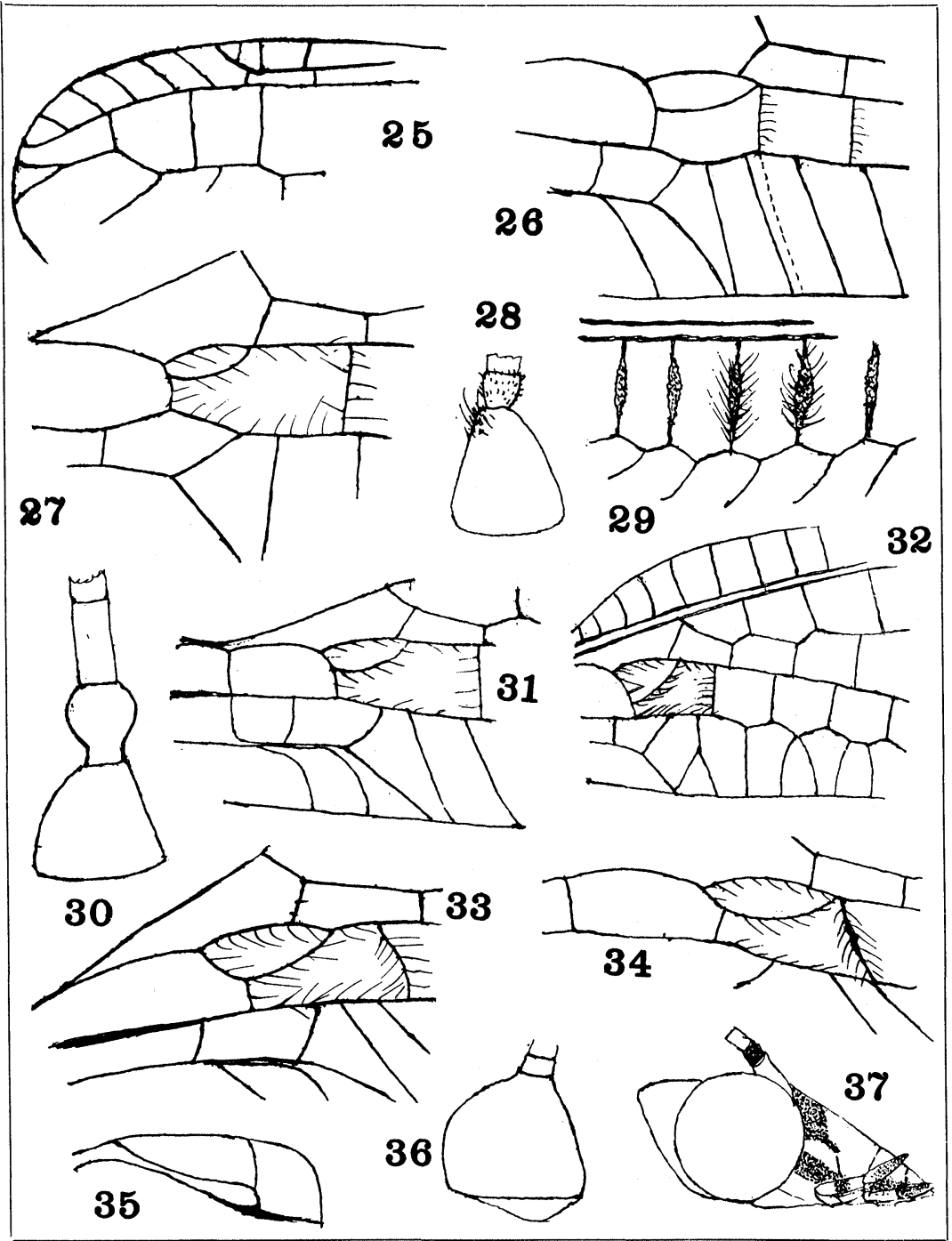

BANKS-CHRYSOPIDAE 

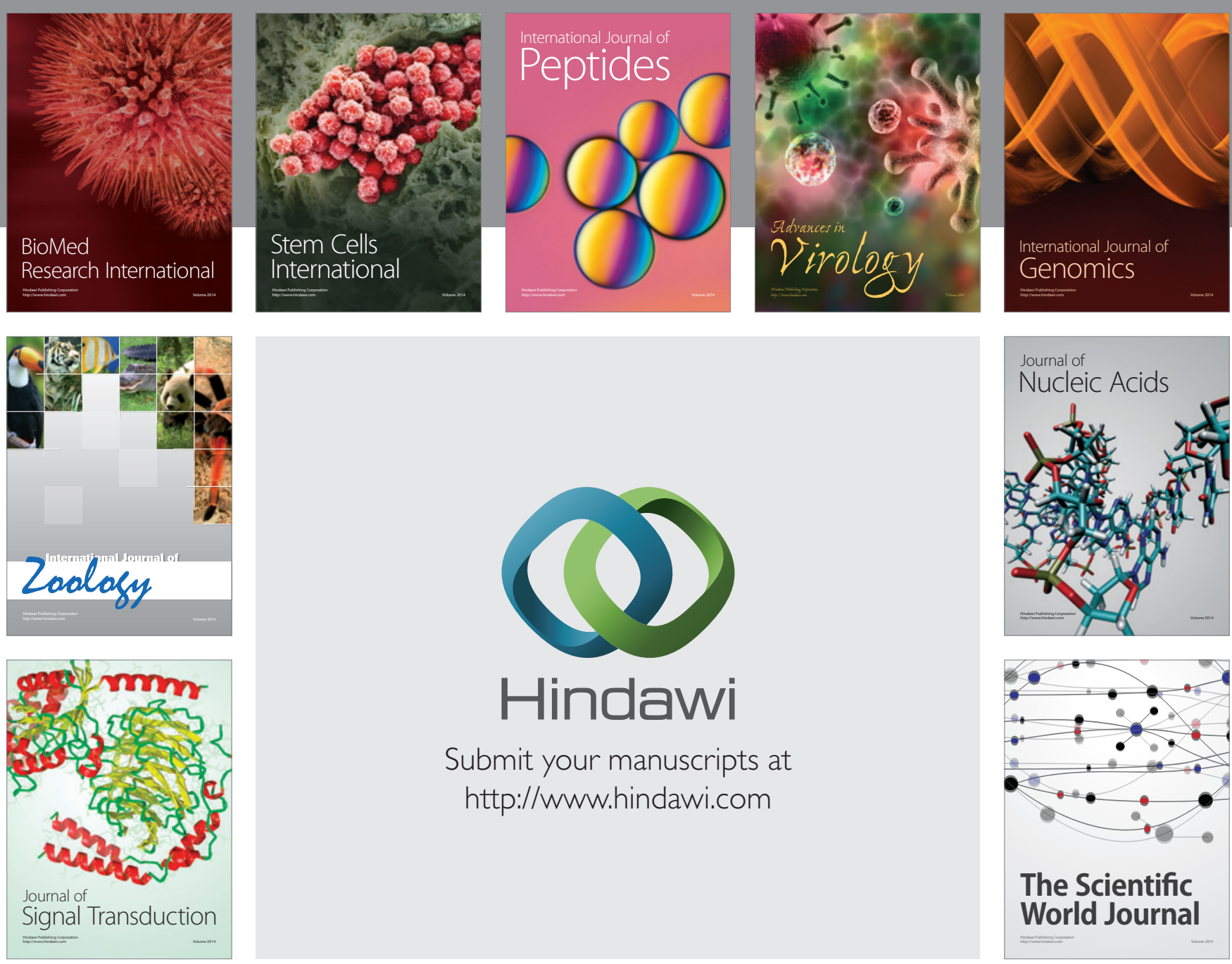

Submit your manuscripts at

http://www.hindawi.com
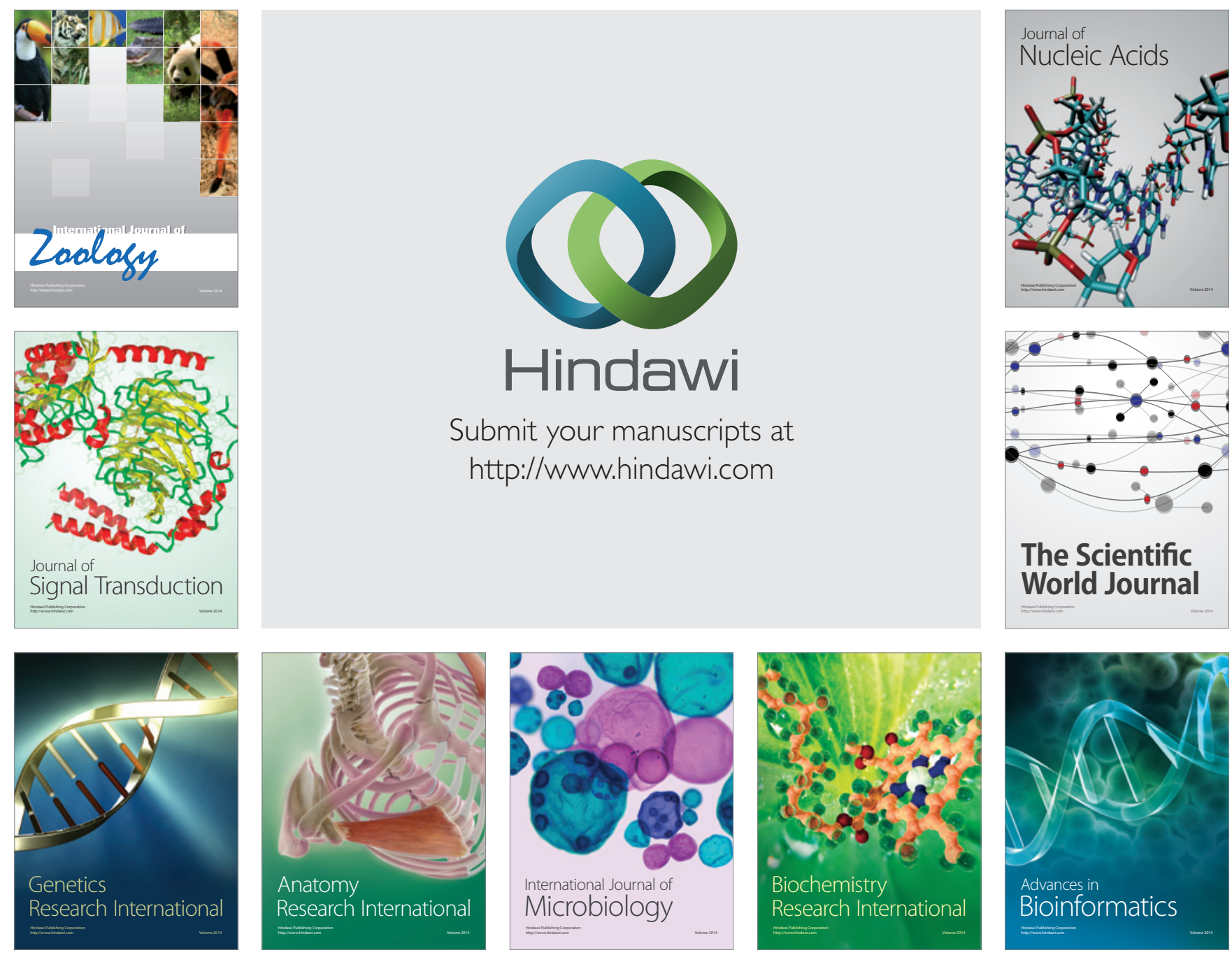

The Scientific World Journal
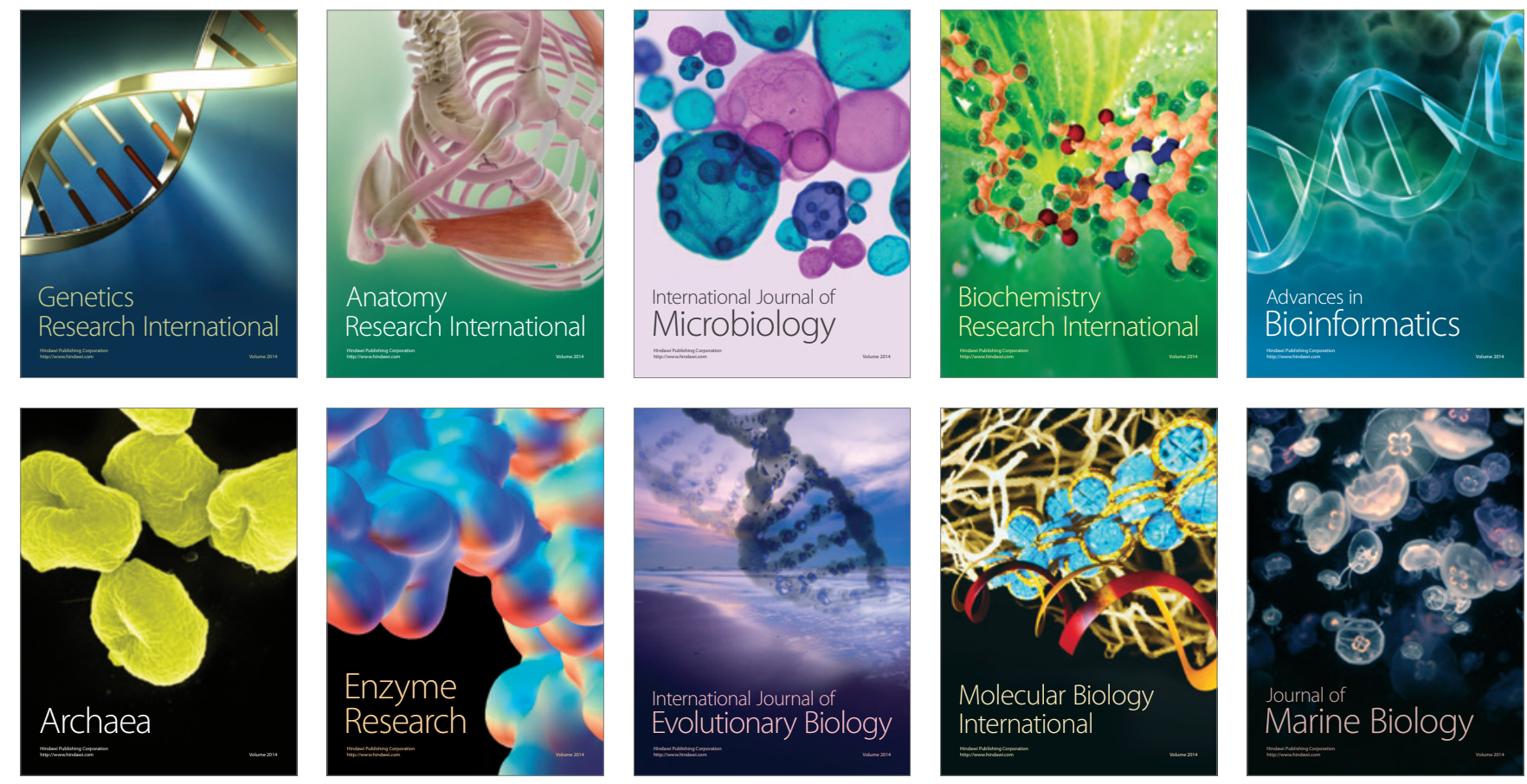